\title{
Population differences in the frequency of the factor V Leiden variant among people with clinically symptomatic protein $\mathrm{C}$ deficiency
}

\author{
Paula J Hallam, David S Millar, Michael Krawczak, Vijay V Kakkar, David N Cooper
}

\begin{abstract}
The factor $V$ Leiden variant, responsible for the phenomenon of activated protein $C$ resistance, was found to be less frequent among British (0.06) and Swedish/Danish $(0 \cdot 15)$ protein $\mathrm{C}$ deficiency patients than previously reported in a Dutch study $(0 \cdot 19)$. In the Swedish population, a significantly increased frequency of the factor $V$ Leiden allele was apparent in protein $C$ deficiency patients as compared to healthy controls. However, this was not found in the British population. Coinheritance of the factor $V$ Leiden variant is therefore unlikely to be the sole determinant of whether a person with protein $\mathrm{C}$ deficiency will come to clinical attention. Nevertheless, when patient data were analysed by type of protein $C$ deficiency, it was noted that the frequency of the factor $V$ Leiden variant was $\mathbf{2 \cdot 8}$-fold higher in type II patients compared to type I patients. A possible explanation of this disparity is discussed.
\end{abstract}

( $($ Med Genet 1995;32:543-545)

A high prevalence of the newly discovered factor V (FV) Leiden variant (Arg506 $\rightarrow$ Gln), ${ }^{1}$ responsible for the phenomenon of activated protein C (APC) resistance, ${ }^{2-6}$ has been recently reported in subjects with clinically symptomatic protein $\mathrm{C}$ deficiency. ${ }^{7}$ Coinheritance of this frequent variant with a protein $\mathrm{C}$ gene lesion could therefore explain the difference in thrombotic risk noted between families with clinically symptomatic (overt) protein $\mathrm{C}$ deficiency and those with the much more common clinically asymptomatic (covert) deficiency state. ${ }^{89}$ In order to examine this postulate, we have determined the prevalence of the FV Leiden variant among unrelated protein $\mathrm{C}$ deficient patients of different ethnic/

Table 1 Frequency of FV Leiden variant in subjects with inherited protein $C$ deficiency and controls by geographical origin

\begin{tabular}{lclll}
\hline Group & No & $\begin{array}{l}\text { FV Leiden } \\
\text { heterozygotes }\end{array}$ & $\begin{array}{l}\text { FV Leiden } \\
\text { homozygotes }\end{array}$ & $\begin{array}{l}\text { FV Leiden allele } \\
\text { frequency }\end{array}$ \\
\hline $\begin{array}{l}\text { Controls } \\
\text { British }\end{array}$ & 65 & 4 & & \\
German & 108 & 7 & 0 & 0.031 \\
$\begin{array}{l}\text { Patients } \\
\text { British }\end{array}$ & 47 & 4 & 0 & 0.032 \\
Swedish/Danish & 34 & 6 & $1(4 \cdot 2)$ & 0.064 \\
Others & 39 & 0 & 2 & 0.147 \\
\hline
\end{tabular}

Figure in brackets denotes the relative risk of protein $\mathrm{C}$ deficiency conferred by homozygosity for the FV Leiden variant. Others: patients of diverse ethnic origin other than British or Swedish/ Danish. geographical origin, all of whom shared a personal history of venous thrombosis.

\section{Materials and methods}

PROTEIN C DEFICIENCY PATIENTS

Blood samples from 120 unrelated patients with (1) a personal history of venous thrombosis, (2) a reduced level of protein $\mathrm{C}$ antigen or activity, and (3) a family history of protein C deficiency or venous thrombosis or both, were collected for analysis. The majority of these patients came from either Great Britain (white origin, $n=47$ ) or Scandinavia (Swedish/ Danish, $n=34$ ) while the remainder was of variable geographical ethnic origin, including whites of other nationalities, AfroCaribbeans, and Asians. A sample of 173 healthy people (108 German, 65 British; all white) was selected as controls.

SCREENING FOR THE FACTOR V LEIDEN LESION A $222 \mathrm{bp}$ fragment of the factor $\mathrm{V}$ gene containing exon 10 (the location of the CGA $\rightarrow$ CAA transition responsible for the Arg506 $\rightarrow$ Gln substitution in FV Leiden) was PCR amplified from DNA derived from the 120 protein $\mathrm{C}$ deficient patients and 173 controls as described. ${ }^{1}$ The amplified fragments were slot blotted onto duplicate Genescreen filters which were then hybridised to end labelled sequence specific oligonucleotide probes to discriminate between the wild type allele and the FV Leiden variant. ${ }^{1}$ Filters were subsequently washed at the discriminant temperature $\left(58^{\circ} \mathrm{C}\right)$ for 20 minutes in $3 \mathrm{~mol} / 1$ tetramethylammonium chloride before autoradiography. ${ }^{10}$

\section{Results and discussion}

FV LEIDEN ALLELE FREQUENCY IN PATIENTS AND CONTROLS

In our sample (table 1), the frequency of the FV Leiden variant was found to be significantly lower among British patients $(0.064)$ than noted previously in a Dutch study ${ }^{7}(0 \cdot 190, \mathrm{n}=$ 48). Comparison by means of a small sample Fisher permutation test assigned an error probability of $p=0.009$ to this finding. Among Swedish/Danish protein $\mathrm{C}$ deficient patients, however, the frequency of FV Leiden $(0 \cdot 147)$ was intermediate and failed to differ significantly from both the British and Dutch data, most probably because of the comparatively small sample size. In the control group, by contrast, the prevalence of FV Leiden 
Table 2 Frequency of FV Leiden variant by protein $C$ deficiency type

\begin{tabular}{lllll}
\hline Protein C deficiency type & No & $\begin{array}{l}\text { FV Leiden } \\
\text { heterozygotes }\end{array}$ & $\begin{array}{l}\text { FV Leiden } \\
\text { homozygotes }\end{array}$ & $\begin{array}{l}\text { FV Leiden allele } \\
\text { frequency }\end{array}$ \\
\hline I & 80 & 5 & 2 & 0.056 \\
II & 13 & 2 & 1 & 0.154 \\
Unknown & 27 & 3 & 0 & 0.056 \\
\hline
\end{tabular}

Type I: plasma activity and antigen values concomitantly reduced. Type II: greater reduction in activity than in antigen reflecting the synthesis of a dysfunctional protein.

variant $(0.031)$ was similar to that noted in the normal Dutch $(0.023),{ }^{7}$ German $(0.032$, table $1)$, and Swedish populations $(0.035) .{ }^{4}$

The extent of association between the FV Leiden allele and protein $C$ deficiency thus appears contentious. On one hand, the frequency of the variant in British protein $\mathrm{C}$ deficient patients is only slightly higher than in controls from the same population (Fisher's $p=0 \cdot 20$ ) and the relative risk ${ }^{11}$ for protein $C$ deficiency conferred by heterozygous or homozygous carriership of the FV Leiden allele is $\mathbf{1} \cdot \mathbf{8}$. In Swedish protein $C$ deficient patients, however, the frequency of the FV Leiden allele is significantly higher than noted in healthy controls from the same population ${ }^{4}(p=$ 0.0001 , by reference to the underlying Bernouilli distribution), and a relative risk of $4 \cdot 1$, conferred by heterozygous or homozygous carriership of the FV Leiden allele, results when a Hardy-Weinberg equilibrium frequency of healthy non-carriers is assumed.

In summary, we conclude that the prevalence of the FV Leiden variant among patients with symptomatic protein $\mathrm{C}$ deficiency may not be consistently as high as previously suggested ${ }^{7}$ and that geographical differences in the pattern of coinheritance of the two traits may exist. Nevertheless, the higher relative risk for protein C deficiency conferred by homozygosity for the FV Leiden variant (table 1, British patients), although subject to considerable sampling variance, suggests that protein $\mathrm{C}$ deficient subjects who are homozygous for the FV Leiden variant are more likely to come to clinical attention than those who are heterozygous.

Two points are, however, worthy of further mention. Firstly, the relative importance of specific protein $\mathrm{C}$ defects could not be properly assessed without the comprehensive characterisation of all the mutations segregating in the 120 families. This rather laborious programme is under way but still incomplete. This notwithstanding, there is currently no evidence for protein $\mathrm{C}$ gene lesions differing in their likelihood of coming to clinical attention. ${ }^{12-14}$ Moreover, a recent study has revealed that founder effects are of relatively minor importance for the geographical distribution of known protein $\mathrm{C}$ gene lesions in European populations. ${ }^{14}$ On the whole, therefore, geographical differences in the protein $\mathrm{C}$ mutational spectrum are unlikely to represent a major contributory factor to the observed population differences in the frequency of the factor $\mathrm{V}$ Leiden variant.

ANALYSIS BY TYPE OF PROTEIN C DEFICIENCY When the total patient data, including those of diverse ethnic/geographical origin ("Others" in table 1), were analysed by type of protein C deficiency, it was noted that the frequency of the FV Leiden variant was $2 \cdot 8$-fold higher in type II patients than in type I patients (table $2)$. Although the significance of this observation was borderline (Fisher's $\mathrm{p}=0.089$ ), and thus awaits confirmation by further studies, we offer the following possible explanation.

Together with protein $S$ and factor V, APC forms a $1: 1: 1$ stoichiometric complex on the phospholipid surface that is capable of inactivating factor VIIIa. ${ }^{15}$ The FV Leiden defect is likely to reduce the level of this inactivating complex. This is because thrombin generation is increased in APC resistant plasma owing to the excess of factor Va. ${ }^{15}$ Factor $\mathrm{V}$ activated by thrombin is, however, inefficient as a cofactor in the inactivation of factor VIIIa. ${ }^{15}$ Although the reduced synthesis of protein $C$, characteristic of type I protein C deficiency state, would presumably reduce the level of factor VIIIa inactivating complex still further, a normal level of factor $V$ is still available to wild type protein $\mathrm{C}$ molecules for complex formation. By contrast, a dysfunctional (type II) protein C molecule might still be able to interact with protein $\mathrm{S}$ and factor $\mathrm{V}$ to generate a nonfunctional complex. Once formed, this inactive complex could sequester factor $\mathrm{V}$ and protein $S$ thereby reducing the amount of factor $\mathrm{V}$ accessible to wild type protein $\mathrm{C}$ (it might also compete with its functional counterpart for access to factor VIIIa). This reduction might explain why carriership of the FV Leiden variant increases the likelihood of clinical detection more dramatically for type II protein $\mathrm{C}$ deficiency than for type I deficiency patients.

We are most grateful to the following colleagues who have contributed blood samples: N N Abdelshaheed, J Allgrove, E Berntorp, D Bevan, P Bolton-Maggs, N de Bosch, J E Braithwaite, J F Burman, M Chisholm, B T Colvin, A Copplestone, R Egbring, J T Epplen, I M Franklin, A Girolami, I R Grant P J Green, F G H Hill, S Holding, B J Hunt, N Lanir, B Laursen, C Legnani, M Layton, P M Mannucci, E Melissari, U Martinowitz, A Minford, E H Moffat, J Reiss, J C Reverter, J Reynaud, M Ryynänen, B Schneider-Rätzke, M Stuhrmann, S Schulamn, G L Scott, R Simioni, L Tengborn, E G D Tuddenham, J Voke, R Wensley, $M$ Winter, $P$ Woods, $B$ Zoll. The generous financial support of Charter plc, British-American Tobacco plc, the Welton Foundation, and Sun Life Assurance Society plc is gratefully acknowledged.

1 Bertina RM, Koeleman BPC, Koster T, et al. Mutation in blood coagulation factor $\mathrm{V}$ associated with resistance to activated protein C. Nature 1994;369:64-7.

2 Dahlbäck B, Carlsson M, Svensson PJ. Familial thrombophilia due to a previously unrecognized mechanism characterized by poor anticoagulant response to activated protein C: prediction of a cofactor to activated protein C. Proc Natl Acad Sci USA 1993;90:1004-8.

3 Griffin JH, Evatt B, Wideman C, Fernandez JA. Anticoagulant protein $\mathrm{C}$ pathway defective in majority of thrombophilic patients. Blood 1993;82:1989-93.

4 Svensson PJ, Dahlbäck B. Resistance to activated protein $\mathrm{C}$ as a basis for venous thrombosis. $N$ Engl ₹ Med 1994; 330:517-22.

5 Dahlbäck B, Hildebrand B. Inherited resistance to activated protein $C$ is corrected by anticoagulant cofactor activity protein $\mathrm{C}$ is corrected by anticoagulant cofactor activity found to be a property of

6 Dahlbäck B. Physiological anticoagulation. Resistance to activated protein $\mathrm{C}$ and venous thromboembolism. F Clin activated protein $C$ and

7 Koeleman BPC, Reitsma PH, Allaart CF, Bertina RM APC-resistance as an additional risk factor for thrombosis in protein C deficient families. Blood 1994;84:1031-5.

8 Miletich J, Sherman L, Broze G. Absence of thrombosis in subjects with heterozygous protein C deficiency. $N$ Engl f Med 1987;317:991-6.

9 Tait RC, Walker ID, Reitsma PH, et al. Prevalence of protein $\mathrm{C}$ deficiency in the healthy population. Thromb Haemost 1995;73:87-93.

10 Wood WI, Gitschier J, Lasky LA, Lawn RM. Base composition-independent hybridization in tetramethylammonium chloride: a method for oligonucleotide screen- 
ing of highly complex gene libraries. Proc Natl Acad Sci USA 1985;82:1585-9.

11 Morton NE. Outline of genetic epidemiology. Basel: Karger, 1988:94-5.

12 Allaart CF, Poort SR, Rosendaal FR, Reitsma PH, Bertina $\mathrm{RM}$, Briët $\mathrm{E}$. Increased risk of venous thrombosis in carriers of hereditary protein $C$ deficiency defect. Lancet 1993;341:134-8.
13 Reitsma PH, Bernardi F, Doig RG, et al. Protein C deficiency: a database of mutations, 1995 update. Thromb

Haemost (in press).
14 Krawczak M, Reitsma PH, Cooper DN. The mutational demography of protein C deficiency. Hum Genet (in press) 5 Shen $L$, Dahlbäck B. Factor $V$ and protein $S$ as synergistic cofactors to activated protein $C$ in degradation of factor VIIIa. F Biol Chem 1994;269:18735-8. 